Hydrology and Earth System Sciences, 6(3), 607-615 (2002) C $\quad$ EGS

\title{
INCA : summary and conclusions
}

\author{
Colin Neal $^{1}$, Paul G. Whitehead ${ }^{2}$ and Nicola Flynn ${ }^{2}$ \\ ${ }^{1}$ Centre for Ecology and Hydrology (Wallingford). Maclean Building, Crowmarsh Gifford, Wallingford, OXON, OX10 8BB, UK \\ ${ }^{2}$ Department of Geography, University of Reading, Whiteknights, PO Box 227, Reading, RG6 2AB, UK \\ Email for corresponding author: cn@ceh.ac.uk
}

\begin{abstract}
This contribution brings to a close a special issue of Hydrology and Earth System Sciences concerning the assessment of nitrogen dynamics in catchments across Europe within a semi-distributed Integrated Nitrogen model for multiple source assessment in Catchments (INCA). The wide range of issues involved in relation to hydrology and within-catchment processes, scale (from small catchments to major river basins), climate (from sub-arctic to Mediterranean regimes) and pollution (atmospheric, agricultural and urban sources) is outlined. Consideration is then given to how well the model has performed and future research requirements are outlined.
\end{abstract}

Keywords: nitrogen, nitrate, ammonium, organic nitrogen, catchments, streams, rivers, river basins

\section{Introduction}

The issue of nitrogen sources, sinks and hydrological transport through ecosystems is an important one in relation to the vitality of ecosystem functioning and the impacts of man (Wade et al., 2002a). These impacts relate primarily to increases in nitrate and ammonium loading to catchments due to atmospheric deposition of pollutants from agriculture and industry, from the excessive use of nitrogenous fertilisers by agriculture and from urban and industrial discharges. For example, excess nitrogen deposition leads to soil, stream and lake acidification and increased nitrogen leaching that affect the vitality and diversity of the land and aquatic ecosystems. Indeed, a very active area of research relates to assessing the critical loading of nitrogen in acid sensitive catchments which varies over time in relation to factors such as climate variability, changing patterns of acidification and land use change (Wright and Rasmussen, 1998a,b; Tietema et al., 2002; Skeffington, 2002). Correspondingly, for agricultural and urban/industrial areas, surface and groundwaters can become contaminated with nitrates leading to problems of eutrophication and excessive weed and algal growth within streams and rivers with a "knock on" effect due to increased nitrogen flux to the estuarine, coastal and open sea environments: there are also water resources implications for the maintenance of potable supplies.

There is strong evidence that the issue of nitrogen contamination of the terrestrial and freshwater environment has shifted over the past 30 years from what was once considered to be a local pollution issue to one of regional dimensions. Indeed, Heathwaite et al. (1993) noted that unless measures are taken to reduce the rate and magnitude of nitrate input to receiving waters, the scale of nitrate pollution might shift towards a continental-scale problem involving widespread pollution of fresh and marine waters. Already there are concerns at the European dimension (Stanners and Bourdeau, 1995; Langusch and Matzner, 2002a,b; Skeffington, 2002). These concerns not only relate to the terrestrial and aquatic environment but also to issues of climate change where nitrous oxide is an important greenhouse gas that is generated from soils and dependent on available mineral nitrogen, soil temperature and water content, available organic compounds and land use (Machefert et al., 2002).

This paper summarises the results of the papers in this Special Issue of HESS dedicated to assessing nitrogen dynamics in catchments across Europe within a modelling framework. For the volume, the work focuses on the 
production of an extension of a semi-distributed Integrated Nitrogen model for multiple source assessment in Catchments (INCA; Whitehead et al., 1998a,b, 2002a; Wade et al., 2002b) in the context of a major initiative dealing with the prediction and management of aquatic nitrogen pollution across Europe (Wade et al., 2002a). The initiative, sponsored by the European Commission is "Integrated Nitrogen Model for European Catchments": contract number EVK1-1999-00011.

\section{Nitrogen dynamics across catchments}

There are many issues of nitrogen dynamics within catchments across Europe (Stanners and Bourdeau, 1995) as well as a vast literature on the subject. However, comment is given on the specific catchment studies outlined in this special issue. Readers are referred to a special issue of Forest Ecology and Management (Wright and Rasmussen, 1998a) dealing with forest decline, acidification of soils and surface waters, and the nutrient enrichment of terrestrial and aquatic ecosystems across Europe as linked to whole catchment manipulation experiments (the NITREX and EXMAN experiments, Wright and Rasmussen, 1998b) and the general work of Burt et al. (1993) on nitrate in the environment.

For the Scandinavian countries, studies in Norway and Finland provided information on nitrogen dynamics in relation to hydrology and the particular significance of snow and snow/ice melt.

The Norwegian study deals with two heath-land catchments in Norway (Kaste and Skjelkvåle, 2002) with similar in size (about $3 \mathrm{~km}^{2}$ ), geology and land cover characteristics but with contrasting climate and nitrogen deposition. One of the sites, Dalelva, in northern Norway is characterised by a cold, Arctic climate with low nitrogen deposition ( 2 to $3 \mathrm{~kg}-\mathrm{N} \mathrm{ha}{ }^{-1} \mathrm{yr}^{-1}$ ): geology is schist and gneiss covered by glacial sediments of similar lithology and rainfall amounts to about $629 \mathrm{~mm} \mathrm{yr}^{-1}$ (average differences between rainfall and runoff are about $226 \mathrm{~mm} \mathrm{yr}^{-1}$ ). The other site, Øygard in southern Norway, has a milder more humid climate with much larger nitrogen deposition from atmospheric pollution (13 to $19 \mathrm{~kg}-\mathrm{N} \mathrm{ha}^{-1} \mathrm{yr}^{-1}$ ): geology is migmatite, gneiss and anorthosite covered by glacial sediments and rainfall is about $2146 \mathrm{~mm} \mathrm{yr}^{-1}$ (average differences between rainfall and runoff are estimated to be about $361 \mathrm{~mm} \mathrm{yr}^{-1}$ ). At Dalelva about half of the annual precipitation occurs as snow and is subsequently discharged through a distinct snowmelt flood. Nitrate levels increased during the growing season typically to around 40 to 100 $\mu \mathrm{g}-\mathrm{N}^{-1}$ just before snowmelt when dilution occurred. In contrast, at Øygard, flood peaks occurred throughout all the seasons, there was no predominant spring flood, nitrate concentrations were much higher (range $\sim 50$ to $\sim 550 \mu \mathrm{g}-\mathrm{N}$ $1^{-1}$ ) and nitrate concentrations did not markedly dilute during floods. Indeed, due to the lack of permanent snow cover and the absence of frost at Øygard, the nitrogen transformation processes may proceed throughout large parts of the winter. Thus, it seems that the contrasting climatic changes have affected both the dynamics of the hydrology and nutrient dilution with increasing flow. In terms of nitrogen speciation, dissolved organic nitrogen is a significant component averaging over $100 \mu \mathrm{g}-\mathrm{N}^{-1}$ at both sites, while ammonium concentrations are particularly low. For dissolved organic nitrogen, the corresponding organic carbon levels are three times higher at Dalelva so that the $\mathrm{C}: \mathrm{N}$ ratio is much higher at Dalelva. At Dalelva, the particularly low inorganic nitrogen concentrations means that organic nitrogen is the main form of dissolved nitrogen. In terms of nitrate flux, there is a negligible net export at Dalelva but a significant output with higher deposition loading at Øygard (about $18 \%$ of the input). Clearly, the work shows that the nitrogen supply at Øygard exceeds the combined plant and microbial demand. There is a near balance at Dalelva.

The Finnish study concerns the Simojoki river basin and its sub-catchments in central/northern Finland (Rankinen et al., 2002). The river discharges to the Baltic Sea, has a catchment area of $3160 \mathrm{~km}^{2}$ and comprises nine sub-basins. The Simojoki river basin is located in the Fenno-Scandian Shield with bedrock comprising granites and gneisses. It is located in the northern boreal zone dominated by forests on mineral (38\%) and organic soil (55\%) with varying types of peat lands. The major tree species are Norway spruce, Scots pine and birch. The river is in a near natural state: the human influences on nitrogen fluxes are forest management and atmospheric nitrogen deposition. Snow cover predominates from November to May; the river freezes from the end of November and the ice cover breaks up around the middle of May and snowmelt-induced spring floods in late April-May dominate the annual hydrological pattern. Annual precipitation averages 650 to $750 \mathrm{~mm} \mathrm{yr}^{-1}$ and mean annual runoff averages 350 to $450 \mathrm{~mm} \mathrm{yr}^{-1}$. Nitrogen uptake by the vegetation, immobilisation and mineralisation in catchment soils, accumulation in the seasonal snow pack and hydrological variation are the predominant factors affecting seasonal nitrate concentrations. In both the boreal mineral and organic forest soils, inorganic nitrogen is usually retained during the growing season and streamwater concentrations are often negligible. Of the nitrogen species, about $80 \%$ is in organic forms with concentrations being fairly uniform at around $400 \mu \mathrm{g}-\mathrm{N}^{-1}$ although they are slightly lower during the early part of the year. Of the 
inorganic species, nitrate (14\%) averages around 90 $\mu \mathrm{g}-\mathrm{N}^{-1}$ with highest concentrations (typically around 220 $\mu \mathrm{g}-\mathrm{N}^{-1}$ ) around snowmelt time (April) with undetectable levels occurring during the summer and autumn months. Ammonium ions make up the remaining inorganic nitrogen contribution and ammonium concentration patterns follow that of nitrate, but at about half the level. The Simojoki basin has a relatively closed inorganic nitrogen cycle similar to that for Dalelva.

The dominant issues in the presentations for the catchments in the Netherlands (Tietema et al., 2002; Raat et al., 2002) and Germany (Langusch and Matzner, 2002a,b) relate to critical loading and modelling within both INCA (Langusch and Matzner, 2002a,b) and other frameworks (SMART2 and MERLIN; Tietema et al., 2002). The modelling aspects are discussed later in the paper. However, the contribution of Raat et al. (2002) which deals with the spatial variability of throughfall and forest floor water content for a Douglas fir stand at the Speuld research site requires comment. Increased atmospheric deposition of nitrogen and sulphur has led to problems in forest ecosystems associated with soil acidification, unbalanced nutrition and high leakage of nitrogen to groundwater. The study showed that both throughfall chemistry and water fluxes as well as forest floor water contents exhibit smallscale spatial patterns over time. Element concentrations are negatively correlated with water fluxes during events (except for ammonium) but element fluxes are not correlated with water fluxes and spatial patterns in forest floor water content do not correlate with the patterns of throughfall. The spatial variability in nitrogen input to the soil and in the water content of the forest floor is considerable in relation to microbial transformation and the temporal dynamics of the nitrogen inputs results in addition of inorganic nitrogen to the forest floor. The Raat et al. (2002) study provides a good example of the heterogeneity that is common when exploring within catchment and within canopy processes (Neal et al., 1994; Robson et al., 1994; Neal, 1997). The results have important implications for process understanding and modelling of nitrogen in forest ecosystems.

For the United Kingdom, the catchment information relates to a spectrum of issues (atmospheric deposition, rural runoff and agricultural and urban pollution). Two papers deal directly with processes, while the remaining papers concern INCA modelling frameworks. The catchment studies relate to process understanding for a series of catchments (from first order stream drainage to catchment areas of up to $4 \mathrm{~km}^{2}$ ) in acidic and acid sensitive areas of the UK (Plynlimon, mid-Wales). At these sites, there is a maritime climate and rainfall is high at around $2500 \mathrm{~mm} \mathrm{yr}^{-1}$. The bedrock is mainly slates and shales and runoff is flashy in response to hydrological events. Nitrate provides the main inorganic nitrogen species for both the undisturbed and felled catchment areas. For the undisturbed areas, the moorland and forested catchments have nitrate concentrations in the range 224 to $560 \mu \mathrm{g}-\mathrm{N}^{-1}$ while the corresponding range for ammonium is 10 to $13 \mu \mathrm{g}-\mathrm{N}^{-1}$. Correspondingly, soluble reactive phosphorus (SRP) concentrations range between 1 and $2 \mu \mathrm{g}-\mathrm{P}^{-1}$. In essence, the catchments are phosphorus limiting in terms of the nutrients. The nitrate concentrations show a strong seasonality with highest concentrations during the winter months when biological activity is at its lowest. However, there are marked year-to-year variations and climatic factors seem to be important in influencing this variability. The effect of felling on stream nitrate, ammonium and SRP concentrations varies depending upon whether the soils are podzols or gleys. For the streams draining the felled podzolic areas, the concentrations of nitrate can be up to an order of magnitude higher than pre-fell values and post-fell concentrations can even be lower than the pre-fell values. However, felling of the podzolic catchments leads to little change in ammonium and SRP concentration. For the gley soils, felling results in an order of magnitude increase in nitrate, ammonium and SRP at the local scale. This is to be expected due to the reducing conditions within the gley soils. However, the increase is barely seen by the time the runoff reaches the main stream so that within-catchment and withinstream processes remove the nitrate, ammonium and SRP fluxes generated with felling. Neal (2002a) proposed that the lack of a nutrient response within the main streams for the gley area reflects the increase in the nutrient limiting species (SRP) with rapid stimulation of biological activity that removes both nitrogen and phosphorus species. An analysis of the impacts of felling for the podzolic areas based on cumulative flux and cumulative flux difference methodologies (Neal, 2002b), shows that the initial phase of felling leads to a net increase in nitrate flux but, as new trees are introduced, increased nutrient uptake occurs. Indeed, after several years post-felling, nitrate fluxes are even lower than pre-fell. It seems that over a forest rotation cycle, the net flux change may be zero as any initial increase of nitrate with felling is counteracted subsequently as nitrate is incorporated into the newly developing biomass. The cumulative flux and cumulative flux change methodologies show that, initially, the streams acidify with felling as nitrate concentrations increase but that the acidification is reversed subsequently due to a combination of reduced nitrate concentrations and reduced mist capture that lowers the sea salt flux. With regard to dissolved organic nitrogen, Chapman et al. (1999) showed for the Plynlimon catchments that the average flow weighted concentrations for nitrate 
and for dissolved organic nitrogen was 278 and 86 $\mu \mathrm{g}-\mathrm{N}^{-1}$, respectively for the moorland areas and 373 and $43 \mu \mathrm{g}-\mathrm{N}^{-1}$, respectively, for the forested areas. Thus, inorganic nitrogen dominates the dissolved nitrogen loading for these catchments except in the summer when nitrate concentrations are particularly low.

The Tweed study (Jarvie et al., 2002) relates to a major rural United Kingdom river basin $\left(4400 \mathrm{~km}^{2}\right)$. Rainfall average is about $990 \mathrm{~mm} \mathrm{yr}^{-1}$ but there is a large altitudinal gradient across the catchment from $2200 \mathrm{~mm} \mathrm{yr}^{-1}$ in the headwater areas to less than $650 \mathrm{~mm} \mathrm{yr}^{-1}$ in the lowlands: runoff averages $572 \mathrm{~mm} \mathrm{yr}^{-1}$. The catchment varies from upland areas of moorland and rough pasture that are used for hill farming to arable tilled regions in the lowlands where cereal crops can be grown. The climate is cool and temperate with average monthly temperatures ranging from $1^{\circ} \mathrm{C}$ in January to $13^{\circ} \mathrm{C}$ in August. Nitrate accounts for about $97 \%$ of the dissolved inorganic nitrogen and ammonium is clearly of secondary importance. The underlying geology is predominantly sedimentary and metamorphosed sedimentary rocks (greywacke, shale, mudstone and limestone). There is a strong gradation in nitrate concentrations from the upper hill farming and moorland areas of the catchment to the agriculturally affected land in the lowland areas (an increase from about 100 to about $400 \mu \mathrm{g}-\mathrm{N}^{-1}$ ). In general, there is a cyclical pattern to nitrate concentrations; the highest values occur in winter when runoff from the soils is at its highest. Elevated nitrate concentrations are also found in some of the smaller tributaries in the west of the region due to sewage inputs and low dilution capacity. Organic forms of nitrogen can also provide an important contribution to the dissolved nitrogen flux, particularly in the upland regions during the summer months (up to $37 \%$ of the nitrogen flux). In a study of nitrogen in streams in upland Scotland, flow weighted annual nitrate and dissolved organic nitrogen varied from 89 to $895 \mu \mathrm{g}-\mathrm{N}^{-1}$ and from 134 to $304 \mu \mathrm{g}-\mathrm{N}^{-1}$, respectively, and the average percentage of dissolved organic nitrogen to total dissolved nitrogen varied from 31 to $57 \%$, depending upon region (Chapman et al., 2001a). Further, companion studies on soil leachates clearly indicate that the generation of dissolved organic nitrogen was linked more to vegetation cover than to temperature differences (Chapman et al., 2001b).

There are two other studies presented for the United Kingdom and these relate to part of the major basin in southeastern England, the Thames. The area is temperatemaritime as the rest of the United Kingdom, but conditions are drier and warmer in the southeastern corner of the country. Within the Thames aquifer recharge from the Cretaceous Chalk areas is highly significant; rainfall averages $718 \mathrm{~mm} \mathrm{yr}^{-1}$ and runoff averages $418 \mathrm{~mm} \mathrm{yr}^{-1}$. One of these studies relates to the Tillingbourne catchment (Whitehead et al., 2002b) a system with conifer and deciduous forest cover underlain by Greensand and clay, which has been impacted by a high acid deposition loading. For this site (93 ha in area), nitrate in deposition and streamwater chemistry over the past 20 years shows a doubling in nitrogen leaching even though nitrogen inputs have reduced substantially. Comparisons of historic and current soils data for $\mathrm{C} / \mathrm{N}$ ratio show a reduction from about 35 to $26 \%$ in the soil. This is consistent with an increase in nitrogen saturation of the major soils in the catchment. Hill et al. (2002) showed that rainfall nitrate flux decreased from 0.56 to $0.28 \mathrm{~g}-\mathrm{N} \mathrm{m} \mathrm{yr}^{-1}$ while throughfall flux increased from 0.31 to $0.87 \mathrm{~g}-\mathrm{N} \mathrm{m} \mathrm{yr}^{-1}$. Correspondingly, flow weighted nitrate concentration increased from 220 to 520 $\mu \mathrm{g}-\mathrm{N}^{-1}$. The other Thames basin study is concerned with the River Lee, which experiences agricultural and urban pollution (Flynn et al., 2002). The Lee is a major tributary of the Thames $\left(1420 \mathrm{~km}^{2}\right.$ area), land cover is predominantly arable farmland and it supplies about a sixth of the drinking water requirements of London. The majority of the reaches within the Lee have concentrations between 6,000 and $10,000 \mu \mathrm{g}-\mathrm{N}^{-1}$; this indicates that the water quality is worse than the European average and is in the lower $10 \%$. The dynamics of nitrate variations show two opposing trends, a dilution of point sewage sources with increasing flow and increased runoff from the agricultural land during storm events. However, the high groundwater component that has been contaminated by high agricultural inputs over the past 50 years means that the nitrate response over time is damped. Details of the impacts of point and diffuse sources of nitrate pollution are discussed later in relation to the INCA modelling.

In terms of the primary influence of agriculture on nitrate in catchments, Ruiz et al. (2002a,b) studied six first order basins with areas of 0.095 to $13.5 \mathrm{~km}^{2}$ in western Brittany, France, and provide a main reference point for these studies. The climate is oceanic (mean temperature $11.4^{\circ} \mathrm{C}$, mean rainfall $1146 \mathrm{~mm} \mathrm{yr}^{-1}$ and mean runoff $694 \mathrm{~mm} \mathrm{yr}^{-1}$ ), agricultural usage is high (77\%) and the bedrock is fractured and weathered granite. Nitrate concentrations vary from catchment to catchment but in general they are high (range in annual average 4500 to $21500 \mu \mathrm{g}-\mathrm{N}^{-1}$ ). In relation to annual budgets, for such small catchments, year-to-year variations in nitrate leaching can be highly significant, even allowing for a "memory effect" within the soil, though nitrate concentrations remain relatively steady within the streams (Ruiz et al., 2002a). While the climatic conditions do not affect the mean nitrate concentration in stream water significantly, groundwater may well play a major role in 
the stream water nitrate concentrations. Ruiz et al. (2002b) explore the dynamics of nitrate concentration variations in the streams, which exhibit contrasting inter-annual and seasonal patterns. They explain the changes using a simple linear store model. The baseflow is considered as a mixture of water from two linear reservoirs with different time constants with mobile stores contributing to discharge and immobile stores where nitrate moves only by diffusion: storm flow accounts for less than $10 \%$ of the annual flux. Ruiz et al. (2002b) stress the importance of the buffering capacity of the catchments and of the mixing of waters with very different residence times and the findings mirror other approaches including fractal processing (Kirchner et al., 2000; Neal and Kirchner, 2000; Beaujouan et al., 2002; Molénat, and Gascuel-Odoux, 2002; Molénat et al., 2002). These findings have important implications over how these types of catchment need to be modelled (Neal, 1997).

The contributions to this volume from Spain relate to field investigations of the hydrology and inorganic nitrogen fluxes for Holm oak and pine forested catchments in the northeast of the country under dry (Butturini and Sabater, 2002) and sub-humid (Avila, 2002; Butturini et al., 2002; Gallart et al., 2002) Mediterranean climate conditions. The influence of climate on hydrology and stream biogeochemistry is evident, and the papers highlight the importance of the transition period from dry to humid conditions on runoff generation (Butturini et al., 2002, Gallart et al., 2002) and nitrogen dynamics (Avila, 2002; Butturini and Sabater, 2002). Detailed studies of this transition period are essential for achieving a comprehensive understanding of how Mediterranean catchments function. These papers show different temporal and spatial scale approaches. Regarding the runoff generation, Gallart et al. (2002) focused on the role of forest in intercepting rainwater, and the temporalspatial variability of soil moisture for the Vallcebre catchments in the Pyrenees: 0.15 to $4.17 \mathrm{~km}^{2}$ in area, with mudstone bedrock, rainfall $924 \mathrm{~mm} \mathrm{yr}^{-1}$ and about $56 \%$ runoff. Butturini et al. (2002) analysed the importance of the local stream-aquifer interaction in the near-stream groundwater zone during the dry and transition periods. This study was for the Fuiosos catchment near to Barcelona (catchment area $10.5 \mathrm{~km}^{2}$ with granite bedrock and rainfall averaging $613 \mathrm{~mm} \mathrm{yr}^{-1}$ ). The nitrogen fluxes are followed through the catchment compartments, with special emphasis to the inorganic atmospheric $\mathrm{N}$ fluxes via wet and dry deposition in a study by Avila (2002). This work related to a small catchment in the Montseny Mountains of Catalonia, La Castanya (5.9 ha in area with bedrock comprising metamorphic rocks, mainly phyllite and gneiss, rainfall 901 $\mathrm{mm} \mathrm{yr}^{-1}$ and runoff $311 \mathrm{~mm} \mathrm{yr}^{-1}$ ). Avila (2002) showed that atmospheric deposition of inorganic nitrogen averaged 15
$\mathrm{kg}-\mathrm{N} \mathrm{ha}{ }^{-1} \mathrm{yr}^{-1}$ over half of which comes from dry deposition. Despite this substantial input flux, most of the inorganic nitrogen was retained within the forest ecosystem. In the stream, nitrate and ammonium concentrations were always less than the limit of detection of $28 \mu \mathrm{g}-\mathrm{N}^{-1}$ at baseflow and nitrate concentrations increased only briefly to 1400 $\mu \mathrm{g}-\mathrm{N}^{-1}$ at stormflow: the export of inorganic nitrogen at the catchment outlet averaged only $0.05 \mathrm{~kg}-\mathrm{N} \mathrm{ha}{ }^{-1} \mathrm{yr}^{-1}$. Butturini and Sabater (2002) examined the storm frequency and magnitude of nitrate changes for a second order stream to the northern end of the Montseny Mountains, Riera Major: catchment area $16.5 \mathrm{~km}^{2}$ with granodiorite bedrock and highly variable rainfall in the range 855 to $1660 \mathrm{~mm} \mathrm{yr}^{-1}$. They showed that nitrate concentrations varied between 150 and $1900 \mu \mathrm{g}-\mathrm{N}^{-1}$ and that the highest concentrations occurred during storm events: high flow events accounted for about a half of the nitrate flux. Butturini and Sabater (2002) showed that the hyporheic zone might act as both a source and a sink of ammonium. They showed that in the hyporheic zone, ammonium concentrations were $\sim 75 \mu \mathrm{g}-\mathrm{N}$ $1^{-1}$, while after storm events concentrations were much lower at $\sim 14 \mu \mathrm{g}-\mathrm{N}^{-1}$ and that the levels occurring in stream runoff averaged $11 \mu \mathrm{g}-\mathrm{N}^{-1}$.

None of the Spanish studies applied the INCA model explicitly, but their findings suggest that modelling of Mediterranean forested catchments requires account to be taken of the ability of the forest compartment to regulate the storm hydrograph by rainwater interception and to increase the nitrogen atmospheric input by capturing airborne substances during the dry periods. To improve the modelling of water and element fluxes during the transition between dry and humid conditions is a daunting task for these catchments.

\section{Model developments, applications and process understanding in the INCA project}

A primary task of the EU-INCA project has been the development of a generic model applicable to the wide range of climatic regimes across Europe with process equations that will work from dry land Mediterranean environments through temperate Atlantic systems to Artic Northern Scandinavian conditions. A thorough review of underlying processes has been undertaken based on the wide experience of the INCA team of scientists and the catchment studies they have undertaken. The basic equations of the INCA model by Whitehead et al. (1998a,b), developed originally for the UK environment, have proved to be an adequate basis for development. However, to cover such a wide 
variety of catchment types and pollution issues, parts of the INCA model have been refined in relation to hydrology and to climate linked with biological processes of nitrogen attenuation. These refinements relate to soil moisture and temperature controls on process parameters, the soil-water retention volumes, the vegetation growth periods and the fertiliser application mechanisms (Wade et al., 2002b); Work on the reformulation and numerical integration of the mass balance equations has ensured that mass balance is maintained. With these changes, it has been possible to apply the model to a range of catchment studies across Europe.

The process of creating a generic model has led to many fundamental ideas on modelling the dynamics of catchments relating, for example, to how nitrogen behaves in Arctic environments in winter and what controls the hydraulic stores in the soil and groundwater system have on $\mathrm{N}$ release. Further, it has been possible to highlight flows or periods of inaccuracy of certain modelling techniques. For example, the Meteorological Office MORECS system for estimation of soil moisture deficit and hydrologically effective rainfall (HER) works well in most situations but can be inaccurate in predicting stream recovery in low rainfall years. This extremely valuable information provides INCA users with guidelines on procedures in certain model applications. Limbrick (2002) presents a method of calculating hydrologically effective rainfall and recharge into chalk aquifers that should be applicable during dry years when the MORECS approach yields unreliable results.

A major innovation has been the development of INCAP, the Phosphorus version of INCA (Wade et al., 2002c). The model developments by Wade et al. (2002c) build on the generic INCA model (Wade et al., 2002b) but replace the nitrogen equations with a new scheme for organic and non-organic phosphorus transport in rivers. The controls on phosphorus transport from catchments are more complex than nitrogen because of the adsorption of phosphorus on sediments and the subsequent transfer of sediments into stream systems. Once in the stream, chemical transformations for phosphorus are significant and complex with equilibrium processes, phosphorus precipitation and phosphorus exchange with bottom sediment pore water. In addition, macrophyte, epiphyte and phytoplankton interactions cause the uptake, loss and transformation of phosphorus. At the same time, sediment in the stream is either recycling phosphorus or transporting it downstream under high flow conditions. Thus, testing of INCA-P in a real catchment situation will be difficult. Nonetheless, excellent progress has been made in an application to the River Kennet (Wade et al., 2001, 2002d). This development is important in that the impacts of the nutrients on the aquatic environment are linked to biological functioning in a connected fashion and there is a major need for an integrated nitrogen and phosphorus model to examine their relative importance and potential nutrient limitation.

Prior to the European project to which this volume is addressed, the model applications of the nitrogen version INCA were limited to three United Kingdom applications: the River Tywi and the Bedford Ouse (Whitehead et al., 1998b) and the upper River Severn (Hill, 2000). Since the commencement of the EU project, there have been new and important applications. Whitehead et al. (2002a), have applied the model to the River Kennet and investigated the impacts of land use changes since the 1930s. In this volume, there are applications to hydrology in UK, Mediterranean and Arctic streams, water quality applications in England, Scotland, Norway, Finland and Germany and new process understanding and critical load techniques in the UK, Germany and the Netherlands.

The hydrological applications have highlighted the need for a refined MORECS approach, as previously discussed, and the importance of spatially distributed rainfall data in large or elongated catchments where rainfall patterns can differ significantly across a catchment (Jarvie et al., 2002; Rankinen et al., 2002). The Finnish application (Rankinen et al., 2002) demonstrated the need to account for snow cover and snowmelt processes that deliver high flows in spring periods.

The water quality modelling studies revealed the importance of nitrogen turnover, and carbon to nitrogen ratio and mineralisation processes in catchments. The Tillingbourne catchment provides an important example of this; it shows an increased flux of nitrogen over a twentyyear period and the model indicates that mineralisation is the principal mechanism for this $\mathrm{N}$ release (Whitehead et al., 2002b). The $\mathrm{C}: \mathrm{N}$ data from the catchment shows a consistent decline over this 20 -year period again indicating that mineralisation rates have changed. The big question is why has this happened? Is it a climatic effect or a tree ageing process or does some other factor control the rate of mineralisation? Closely tied to these in-catchment nitrogen processes is the concept and application of critical load strategies. This has evolved as a technique for setting pollution control strategies across Europe used by Government and International Agencies such as UNECE.

The research in this volume indicates that the concept of steady state critical loads may be improved significantly by accounting for the dynamics of nitrogen response. INCA has been used by Langusch and Matzner (2002a,b) to estimate the dynamic controls on critical loads and demonstrates that critical loads can change significantly from year to year. This has important implications for pollution control strategies based on critical load techniques: 
similar dynamical critical load approaches are evaluated by Tietema et al. (2002) using the SMART 2 and MERLIN models.

INCA has been used to investigate the impacts of land use change and climatic change. The climate change scenarios based on GCM model outputs from the Hadley Centre for Climatic Change have been applied to the River Kennet INCA simulation by Limbrick et al. (2000) and show that hydrological patterns in groundwater dominated catchments will change with lower late summer flows and high winter flows. This will undoubtedly affect in-stream chemistry and biology as dilution of effluents will be reduced in summer and macrophytes, epiphyte and phytoplankton dynamics will be impacted by the low flows and higher nutrient concentrations. The Tweed study by Jarvie et al. (2002) shows how land use change along a catchment can alter the nitrogen profile significantly; nitrate concentrations can increase by a factor of four as arable land-use increases and natural and moorland declines. This land-use impact has been examined in the River Kennet Study by Whitehead et al. (2002a) which shows that the 1930s land use gave rise to much lower nitrogen levels in groundwater and, hence, in the River Kennet System. The application of INCA to the River Lee by Flynn et al. (2002) indicates that the conversion of arable land to ungrazed vegetation (e.g. set aside, pasture or woodland) would result in substantial reductions in nitrogen in the Upper Lee river system. Importantly, from an environmental management perspective, the inclusion of riparian buffer strips is shown to be less successful in reducing nitrate in rivers. Buffer strips are often thought to be the solution to in-stream nutrient problems but INCA indicates this may not be the case. The urban drainage and effluents considerably affect the water quality and biological functioning of the Lee and it is predicted that reductions in $\mathrm{N}$ in effluent discharges will significantly reduce $\mathrm{N}$ concentrations in rivers. Thus, preliminary results of climatic and land-use change indicate that INCA is indeed a useful tool for evaluating nitrogen controls and processes in catchments.

\section{Conclusions}

The issue of an integrated nitrogen model for European catchments is an important but daunting one. The extent of climate variability, from arctic and sub-arctic climates to temperate-maritime, to continental and Mediterranean regimes, is great. Indeed, even in describing the hydrology across the region, several factors emerge:

- The relative importance and distribution of wet deposition and snow.
- The contrasting annual rainfall volumes (from about 2500 to almost $0 \mathrm{~mm} \mathrm{yr}^{-1}$ ).

- The contrasting severity and distribution of rainfall.

- The cases where stream flow ceases or reduces substantially under the conditions of extremes of cold or aridity.

- The heterogeneity of many of the systems being examined.

In describing the nitrogen dynamics within catchments, the effects of hydrological complexity and variability are compounded by the variability in inputs and process. The variability in input has two components. Firstly, there are large variations in atmospheric inputs, associated with contrasting pollution climates. Secondly there are contrasting inputs from agricultural and urban sources. The variability of process relates to the relative importance of within catchment and within stream mechanisms that attenuate the nitrogen flux and change the chemical speciation.

In broad terms, the catchment studies presented in this special issue, when coupled with associated material, show approximately five typologies of average nitrate levels:

- 0 to $150 \mu \mathrm{g}-\mathrm{N}^{-1}$. This range applies for the most pristine areas with low atmospheric nitrogen contamination or areas with high biological uptake of atmospheric inputs of pollutant nitrogen.

- 150 to $400 \mu \mathrm{g}-\mathrm{N}^{-1}$. The averages in this range occur for relatively undisturbed areas with some atmospheric nitrogen contamination.

- 400 to $2000 \mu \mathrm{g}-\mathrm{N}^{-1}$. This range applies for the rural catchments. The concentrations in this group increase with agricultural and population inputs.

- 2000 to $8000 \mu \mathrm{g}-\mathrm{N}^{-1}$. These concentrations occur as agricultural inputs and urban sources become much more important.

- 8000 to over $20000 \mu \mathrm{g}-\mathrm{N}^{-1}$. These concentrations occur where there are major urban/industrial or agricultural contamination and where potential for dilution is low.

In terms of the INCA modelling work, the results presented in this volume are clearly satisfying in three ways.

1. Scientists with a wide range of expertise, knowledge and scientific outlook have examined the model for a wide range of catchments: there has been a major peer group scrutiny that models are rarely subjected to. Clearly there are differences in emphasis in modelling structures within and outside the programme group and issues such as complexity, full representation of process 
and the study of highly heterogeneous systems remain to be addressed (Hauhs et al., 1996; Kirchner et al., 2000; Beaujouan et al., 2002; Molénat, and GascuelOdoux, 2002; Molénat et al., 2002). Nonetheless, the development of an updated INCA model (Wade et al., 2002b) has been highly successful in the development of a robust distributed model of intermediate complexity for nitrogen.

2. The model has been applied successfully in a wide range of environmental circumstances.

3. Several leading research groups across Europe are now conversant with the use of the model in explorative, descriptive and predictive ways. They provide nucleation centres for new applications across a range of environmental and management settings.

The updated INCA model is now available for research and scenario modelling purposes from Paul Whitehead.

\section{Acknowledgements}

The authors thank the enthusiastic and stimulating contributions of the participants to the INCA modelling programme across Europe: Susana Bernal, Annemarie Bastrup-Birk, Dan Butterfield, Andrea Butturini, Nancy Dise, Patrick Durand, Martin Forsius, Kirsti Granlund, Per Gundersen, Helen Jarvie, Öyvind Kaste, Lea Kauppi, JensJohann Langusch, Ahti Lepisto, Keith Lobley, Severine Machefert, Eugènia Marti, Egbert Matzner, Lucy O'Shea, Klaasjan Raat, Katri Rankinen, Laurent Ruiz, Francesc Sabater, Richard Skeffington, Albert Tietema and Andrew Wade

The authors and the participants of the INCA project are very grateful to Drs Hartmut Barth and Andrea Tilche for providing support under the EU research programme "Integrated Nitrogen Model for European Catchments": contract number EVK1-1999-00011.

The authors are most appreciative of the editorial contribution by Jim McCulloch, whose skills and drive are both commendable and remarkable.

\section{References}

Avila, A., 2002. Nitrogen circulation in a Mediterranean holm oak forest, La Castanya, Montseny, north eastern Spain. Hydrol. Earth Syst. Sci., 6, 551-557.

Beaujouan, V., Durand, P., Ruiz, L., Aurousseau, P. and Cotteret, G., 2002. A hydrological model dedicated to topography-based simulations of nitrogen transfer and transformation: rationale and application to the geomorphology-denitrification relationship. Hydrol. Process., 16, 493-507.
Burt, T.P., Heathwaite A.L. and Trudgill, S.T., 1993. Nitrate; processes, patterns and management. Wiley, Chichester, UK, 444pp.

Butturini, A., Bernal, S., Sabater, S. and Sabater, F., 2002. The influence of riparian-hyporheic zone on the hydrological responses in an intermittent stream. Hydrol. Earth Syst. Sci., 6, $515-525$.

Butturini, A. and Sabater, F., 2002. Nitrogen concentrations in a small Mediterranean stream: 1. Nitrate. II. Ammonium. Hydrol. Earth Syst. Sci., 6, 539-550.

Chapman, P.J., Edwards, A.C., Reynolds, B. and Neal, C., 1999. The nitrogen composition of streams draining grassland and forested catchments: influence of afforestation on the nitrogen cycle in upland ecosystems. Proc. of IUGG 99 Symp., Impact of land-use change on nutrient loads from diffuse sources, HS3, IAHS Pub. no. 257, 17-26.

Chapman, P.J., Edwards, A.C. and Cresser, M.S., 2001a. The nitrogen composition of streams in upland Scotland: some regional and seasonal differences. Sci. Total. Envir., 265, 6583.

Chapman, P.J., Williams, B.L. and Hawkins, A., 2001b. Influence of temperature and vegetation cover on soluble inorganic and organic nitrogen in a spodosol. Soil Biochem., 33, 1113-1121.

Flynn, N.J., Paddison, T. and Whitehead, P.G., 2002. INCA modelling of the Lee system: Strategies for the reduction of nitrogen loads. Hydrol. Earth Syst. Sci., 6, 467-483.

Gallart, F., Llorens, P., Latron, J. and Regues, D., 2002. Hydrological processes and their seasonal controls in a small Mediterranean mountain catchment in the Pyrenees. Hydrol. Earth Syst. Sci., 6, 527-537.

Hauhs, M., Neal, C., Hooper, R. and Christophersem, N., (Eds.), 1996. Modelling in environmental studies. Sci. Total. Envir., 183, 185pp.

Heathwaite, A.L., Burt, T.P. and Trudgill, S.T., 1993. Overview the nitrate issue. In: Nitrate; processes, patterns and management, T.P. Burt, A.L. Heathwaite and S.T. Trudgill (Eds.), Wiley, Chichester, UK, 3-21.

Hill, T., 2000. Dynamic Modelling and Analysis of Hydrochemistry in Upland Forested Catchments. PhD Thesis, University of Reading. Aquatic Environments Research Centre, The University of Reading, Department of Geography, Whiteknights, P.O. Box 227, Reading, RG6 6AB, UK. 199pp.

Hill, T.J., Skeffington, R.A. and Whitehead, P.G., 2002. Recovery from acidification in the Tillingbourne catchment, southern England: catchment description and preliminary results. Sci. Total. Envir., 282-283, 81-97.

Jarvie, H.P., Wade, A.J., Butterfield, D., Whitehead, P.G., Tindall, C.I., Virtue, W.A., Dryburgh, W. and McGraw, A., 2002. Modelling nitrogen dynamics and distributions in the River Tweed, Scotland: an application of the INCA model. Hydrol. Earth Syst. Sci., 6, 433-453.

Kaste, O. and Skjelkvåle, B.L., 2002. Nitrogen dynamics in runoff from two small heathland catchments representing opposite extremes with respect to climate and $\mathrm{N}$ deposition in Norway. Hydrol. Earth Syst. Sci., 6, 351-362.

Kirchner, J.W., Feng, X.H. and Neal C., 2000. Catchment-scale advection and dispersion as a mechanism for fractal scaling in stream tracer concentrations. J. Hydrol., 254, 81-100.

Langusch, J.J. and Matzner, E., 2002a. N fluxes in two nitrogen saturated forested catchments in Germany: Dynamics and modelling with INCA. Hydrol. Earth Syst. Sci., 6, 383-394.

Langusch, J.J. and Matzner, E., 2002b. Long-term modelling of nitrogen turnover and critical loads in a forested catchment using the INCA model. Hydrol. Earth Syst. Sci., 6, 395-402. 
Limbrick, K.J., 2002. Estimating daily recharge to the Chalk aquifer of Southern England - a simple methodology. Hydrol. Earth Syst. Sci., 6, 485-495.

Limbrick, K.J., Whitehead, P.G., Butterfoeld, D. and Reynard, N., 2000. Assessing the potential impacts of various climate change scenarios on the hydrological regime of the River Kennet at Theale, Berkshire, south-centra England, UK: an application and evaluation of the new semi-distributed model, INCA. Sci. Total Environ., 251/252, 539-556.

Machefert, S.E., Dise, N.B., Goulding K.W.T. and Whitehead, P.G., 2002. Nitrous oxide emission from a range of land-uses across Europe. Hydrol. Earth Syst. Sci., 6, 325-337.

Molénat, J. and Gascuel-Odoux, C., 2002. Modelling flow and nitrate transport in groundwater for the prediction of water travel times and of consequences of land use evolution on water quality. Hydrol. Process., 16, 479-492.

Molénat, J., Durand, P., Gascuel-Odoux, C., Davy, P. and Gruau, G., 2001. Mechanisms of nitrate transfer from soils to stream in an agricultural watershed of French Brittany. Water Air Soil Pollut., 133, 161-183.

Neal, C., 1997. A view of water quality from the Plynlimon watershed. Hydrol. Earth Syst. Sci., 1, 743-754.

Neal, C., Ryland, G., Conway, T., Jeffery, H.A., Neal, M., Robson, A.J., Smith, C.J. and Walls, J., 1994. Interception of chemicals at a forest edge, for a rural low lying site at Black Wood, Hampshire, southern England. Sci. Tot. Environ., 142, 127-141.

Neal, C., 2002a. Nutrient concentrations and fluxes for podzolic and gley soils at Plynlimon, mid-Wales: implications for modelling inorganic nitrogen and phosphorus in upland UK environments. Hydrol. Earth Syst. Sci., 6, 403-420.

Neal, C., 2002b. Assessing environmental impacts on stream water quality: the use of cumulative flux and cumulative flux difference approaches to deforestation of the Hafren Forest, midWales. Hydrol. Earth Syst. Sci., 6, 421-432.

Neal, C. and Kirchner, J.W., 2000. Sodium and chloride levels in rainfall, mist, streamwater and groundwater at the Plynlimon catchments, mid-Wales: inferences on hydrological and chemical controls. Hydrol. Earth Syst. Sci., 4, 295-310.

Raat, K.J., Draaijers, G.P.J., Schaap, M.G., Tietema, A. and Verstraten J.M., 2002. Spatial variability of throughfall water and chemistry and forest floor water content in a Douglas fir forest stand. Hydrol. Earth Syst. Sci., 6, 363-374.

Rankinen, K., Lepisto, A. and Granlund, K., 2002. Hydrological application of the INCA (Integrated Nitrogen in Catchments) model with varying spatial resolution and nitrogen dynamics in a northern river basin. Hydrol. Earth Syst. Sci., 6, 339-350.

Robson, A.J., Neal, C., Ryland, G.P. and Harrow, M., 1994. Spatial variations in throughfall chemistry at the small plot scale. $J$. Hydrol., 158, 107-122.

Ruiz, L., Abiven, S., Durand, P., Martin, C., Vertes, F. and Beaujouan, V., 2002a. Effect of nitrate concentration in stream water of agricultural practices in small catchments in Brittany. I - Annual nitrogen budgets. Hydrol. Earth Syst. Sci., 6, 497505.

Ruiz, L., Abiven, S., Martin, C., Durand, P., Beaujouan, V. and Molenat, J., 2002b. Effect of nitrate concentration in stream water of agricultural practices in small catchments in Brittany. II - Temporal variations and mixing processes. Hydrol. Earth Syst. Sci., 6, 507-513.

Skeffington, R., 2002. European nitrogen policies and nitrate in rivers and the use of the INCA model. Hydrol. Earth Syst. Sci., 6, 315-324.
Stanners, D. and Bourdeau, P., (Eds.), 1995. Europe's Environment: The Dobøišs Assessment. European Environment Agency: office for official publications of the European Communities (Luxembourg), 676pp.

Tietema, A., Mol-Dijkstra, J.P., Kros, J. and and de Vries, W., 2002. Dynamic nitrogen critical loads during forest stand development in a Douglas fir forest analysed with two nitrogen models SMART2 and MERLIN. Hydrol. Earth Syst. Sci., 6, 375-382.

Wade, A.J., Hornberger, G.M., Jarvie, H.P. and Flynn, N., 2001. On modelling the mechanisms that control in-stream phosphorus, macrophyte and epiphite dynamics: an assessment of a new model using general sensitivity analysis. Water Resour, Res., 37, 2777-2792.

Wade, A.J., Whitehead, P.G. and O'Shea L.C.M., 2002a. The prediction and management of aquatic nitrogen pollution across Europe: An introduction to the Integrated Nitrogen in European Catchments project (INCA). Hydrol. Earth Syst. Sci., 6, 299313.

Wade A. J., Durand, P., Beaujouan, V., Wessel, W.W., Raat, K.J., Whitehead, P.G., Butterfield, D., Rankinen, K. and Lepisto A., 2002b. A nitrogen model for European catchments: INCA, new model structure and equations. Hydrol. Earth Syst. Sci., 6, 559582 .

Wade, A.J., Whitehead, P.G., and Butterfield, D., 2002c. The Integrated Catchments Model of Phosphorus Dynamics (INCAP), a new approach for multiple source assessment in heterogeneous river systems: model structure and equations. Hydrol. Earth Syst. Sci., 6, 583-606.

Wade, A.J., Whitehead, P.G., Hornberger, G.M., Jarvie, H.P. and Flynn, N., 2002d. On modelling the impacts of phosphorus stripping at sewage works on in-stream phosphorus and macrophyte/epiphyte dynamics: a case study for the River Kennet. Sci. Tot. Environ., 282-283, 395-416.

Whitehead, P.G., Wilson, E.J. and Butterfield, D., 1998a. A semidistributed Integrated Nitrogen model for multiple source assessment in Catchments (INCA): Part I - model structure and process equations. Sci. Tot. Environ., 210/211, 547-558.

Whitehead, P.G., Wilson, E.J., Butterfield, D. and Seed, K., 1998b. A semi-distributed Integrated Nitrogen model for multiple source assessment in Catchments (INCA): Part II - application to large river basins in south Wales and Eastern England. Sci. Total Envir., 210/211, 559-584.

Whitehead, P.G., Johnes, P.J. and Butterfield, D., 2002a. Steady state and dynamic modelling of nitrogen in the River Kennet: impacts of land use change since the 1930s. Sci. Tot. Environ., 283-284, 417-434.

Whitehead, P.G., Lapworth, D.J., Skeffington, R.A., and Wade A.J., 2002b. Excess nitrogen leaching and $\mathrm{C} / \mathrm{N}$ decline in the Tillingbourne catchment, Southern England: INCA process modelling for current and historic time series. Hydrol. Earth Syst. Sci., 6, 455-466.

Wright, R.F. and Rasmussen, L., 1998a (Eds). The whole ecosystem experiments of the NITREX and EXMAN projects. Forest Ecol. Manage., 101, 363pp.

Wright, R.F. and Rasmussen, L., 1998b. Introduction to the NITREX and EXMAN projects. Forest Ecol. Manag., 101, 18. 